\title{
PENGARUH PENERAPAN PENDEKATAN SAINTIFIK MENGGUNAKAN MODEL PEMBELAJARAN DISCOVERY DAN KOOPERATIF TIPE STAD TERHADAP KEMAMPUAN BERPIKIR KREATIF PESERTA DIDIK SDN 13 AMPENAN
}

\section{THE EFFECT OF APPLYING SCIENTIFIC APPROACH USING DISCOVERY LEARNING AND COOPERATIVE LEARNING STAD MODEL ON STUDENTS' CREATIVE THINKING ABILITY AT SDN 13 AMPENAN.}

\author{
Muhammad Ishak ${ }^{1}$, Dwi Soelistya Dyah Jekti ${ }^{2}$, Nyoman Sridana ${ }^{2}$ \\ ${ }^{1}$ PUSLITBANGDA Kwartir Daerah Nusa Tenggara Barat \\ ${ }^{2}$ Program Studi Magister Pendidikan IPA Program Pascasarjana Universitas Mataram \\ Email:ishak.muhammad@ymail.com, soelistya.dj@gmail.com, sridana60@gmail.com
}

Received: 15 Februari 2017; Accepted: 25 Maret 2017

\begin{abstract}
Abstrak. Penelitian ini bertujuan untuk mengetahui pengaruh penerapan pendekatan saintifik menggunakan model pembelajaran discovery terhadap kemampuan berpikir kreatif peserta didik SDN 13 Ampenan. Jenis penelitian adalah quassi ekperiment dengan disain Pretes-Posttes Non Equivalen Control Group Design. Populasi penelitian adalah peserta didik kelas V SDN 13 Ampenan kemudian sampelnya dipilih kelas VC sebagai kelas eksperimen dan kelas VD sebagai kelas kontrol. Instrument penelitian menggunakan tes kemampuan berpikir kreatif dalam bentuk soal uraian. Data dianalisis menggunakan anakova. Berdasarkan hasil penelitian dapat disimpulkan bahwa terdapat pengaruh penerapan pendekatan saintifik menggunakan model pembelajaran discovery dan kooperatif tipe STAD terhadap kemampuan berpikir kreatif peserta didik dan kemampuan berpikir kreatif kelas eksperimen yang menerapkan pendekatan saintifik menggunakan model pembelajaran discovery lebih tinggi dibandingkan dengan kelas kontrol yang menggunakan model pembelajaran kooperatif tipe STAD.
\end{abstract}

Kata kunci: Saintifik, Discovery, Berpikir Kreatif

Abstract. This research was aimed to identifying the effect of applying scientific approach using discovery learning model on students' creative thinking ability at SDN 13 Ampenan. This was a quassi experimental research which employed Pretes-Posttes Non Equivalen Control Group Design. The population of this research was students at Grade V SDN 13 Ampenan, VC as the experimental class and VD as the control class. To test students' creative thinking ability, the researchers used essay test as the research instrument. The data was analyzed by using anacova. Based the usult of the research, there was effect of applying scientific approach using discovery learning and cooperative learning model in type of STAD on students' creative thinking ability, and it can be cancluded that the experimental class which applied scientific approach using discovery learning has well considered compared to control class which applied scientific approach using cooperative learning model in type of STAD.

Key words: Scientific, Discovery, STAD, Creative Thinking.

\section{PENDAHULUAN}

Peningkatan mutu pendidikan sangat ditentukan oleh guru sebagai pendidik dalam pencapaian tujuan pendidikan yang diharapkan. Dengan kata lain guru menempati titik sentral pendidikan agar guru mampu menunaikan tugasnya dengan baik, maka terlebih dahulu harus memahami hal-hal yang berhubungan dengan proses pembelajaran seperti halnya proses pendidikan pada umumnya. Dengan demikian peran guru yang sangat penting adalah mengaktifkan dan mengefisienkan proses belajar di sekolah termasuk di dalamnya penggunaan alat peraga yang sesuai. Dengan pendidikan akan lahir generasi-generasi penerus yang berkualitas dan diharapkan membawa perubahan kearah yang lebih baik. Kualitas pendidikan tidak terlepas dari pelaksanaan pembelajaran yang dilakukan pada jenjang satuan pendidikan [1].

Guru memegang peranan strategis terutama dalam upaya membentuk watak bangsa melalui pengembangan kepribadian dan nilai-nilai yang diinginkan. Peranan guru sulit digantikan mesin dan teknologi yang canggih. Penggunaan teknologi dapat dimanfaatkan dalam proses belajar mengajar dan termasuk dapat membuat peserta didik belajar lebih cepat. Hal tersebut disebabkan banyak faktor dan proses-proses pendidikan yang tidak dapat digantikan oleh teknologi. 
Pendekatan saintifik dapat meningkatkan kemampuan berpikir peserta didik dan keaktifan peserta didik dalam pembelajaran [2]. Pembelajaran melalui pendekatan saintifik adalah proses pembelajaran yang dirancang sedemikian rupa agar peserta didik secara aktif mengontruksi konsep, hukum atau prinsip melalui tahapan-tahapan mengamati, merumuskan masalah, mengajukan atau merumuskan hipotesis, mengumpulkan data dengan berbagai teknik, menganalisis data, menarik kesimpulan dan mengomunikasikan konsep, hukum atau prinsip yang ditentukan [3].

Pendekatan saintifik dipadukan dengan berbagai model pembelajaran yang dapat menopang proses belajar mengajar agar terlaksana dengan baik. Pemilihan pendekatan tematik dan/atau tematik terpadu dan/atau saintifik dan/atau inkuiri dan penyingkapan (discovery) dan/atau pembelajaran yang menghasilkan karya berbasis pemecahan masalah (project based learning) disesuaikan dengan karakteristik kompetensi dan jenjang pendidikan. Penilaian tidak hanya pada aspek pengetahuan, melainkan sikap dan keterampilan juga dilakukan untuk meningkatkan kemampuan peserta didik secara utuh.

Model pembelajaran discovery merupakan proses pembelajaran yang merangsang kemampuan peserta didik untuk memecahkan permasalahan melalui pengolahan data yang terkumpul untuk membuktikan suatu konsep yang terdapat dilingkungan belajar. Sintaks pembelajaran tersebutxadalah: 1) stimulasi/pemberian rangsangan, 2) pernyataan/identifikasi masalah, 3) pengumpulan data, 4) pengolahan data, 5) pembuktian, 6) menarik kesimpulan/generalisasi [4].

Model pembelajaran kooperatif merupakan sebuah kelompok strategi pengajaran yang melibatkan peserta didik bekerja secara kolaborasi untuk mencapai tujuan bersama. Model pembelajaran kooperatif tipe $S T A D$ tidak hanya unggul dalam membantu peserta didik memahami konsep-konsep sulit, tetapi juga sangat berguna untuk menumbuhkan kemampuan interaksi antara guru dan peserta didik, meningkatkan kerja sama, kreativitas, berpikir kritis serta ada kemauan membantu teman [5-7].

Pendekatan saintifik menggunakan model pembelajaran discovery dan model pembelajaran kooperatif tipe STAD merupakan model pembelajaran yang diharapkan dapat meningkatkan hasil belajar dan kemampuan berpikir kreatif peserta didik melalui proses belajar mengajar seperti mengamati, menanya, mengumpulkan data mengasosiasi dan mengkomunikasikan.

Kemampuan berpikir tingkat tinggi diantaranya meliputi kemampuan berpikir kritis dan kreatif. Kemampuan berpikir baik kemampuan berpikir kritis maupun berpikir kreatif merupakan hal penting dan sangat diperlukan peserta didik untuk menghadapi persoalan hidup di masa yang akan datang [8].

Kemampuan berpikir kreatif merupakan potensi yang dimiliki oleh setiap manusia [9]. Upaya yang dilakukan dapat dari segi materi, proses pembelajaran, perbaikan dan dukungan sarana prasarana, peningkatan kemampuan guru dalam mengajar melalui penataran atau pelatihan, pengurangan atau pembagian materi menjadi bagian-bagian yang lebih sederhana (penyederhanaan muatan materi dalam kurikulum) atau peningkatan mutu input (peserta didik) di sekolah. Aktivitas mental untuk mengembangkan atau menemukan ide-ide asli (orisinil), estetis, konstruktif yang berhubungan dengan pandangan konsep, dan menekankan pada aspek berpikir intuitif dan rasional [10]. Berpikir kreatif adalah salah satu keterampilan berpikir yang bisa dikembangkan dalam pembelajaran IPA [11].

Berdasarkan latar belakang diatas maka tujuan dari penlitian ini adalah: (1) Mengetahui pengaruh penerapan pendekatan saintifik menggunakan model pembelajaran discovery terhadap kemampuan berpikir kreatif peserta didik SDN 13 Ampenan, (2) Mengetahui pengaruh penerapan pendekatan saintifik dengan model pembelajaran kooperatif tipe STAD terhadap kemampuan berpikir kreatif peserta didik SDN 13 Ampenan, dan (3) Membandingkan pengaruh penerapan pendekatan saintifik dengan model pembelajaran discovery dan kooperatif tipe STAD terhadap kemampuan berpikir kreatif peserta didik SDN 13 Ampenan.

\section{METODE}

Penelitian ini dikategorikan sebagai penelitian ekperimen semu (quasi experiment dengan desain Pretes-Posttes Non Equivalen Control Group Design [12] rancangan penelitian menggunakan model faktorial $2 \times 2$. Secara singkat rancangan penelitian ini dapat dilihat pada Tabel 1.

$$
\text { Variabel bebas penelitian adalah }
$$
pendekatan saintifik menggunakan model pembelajaran discovery dan model pembelajaran kooperatif tipe STAD. Variabel terikatnya adalah kemampuan berpikir kreatif dan Variabel moderatornya adalah kemampuan awal peserta didik yang terdiri kemampuan tinggi dan kemampuan rendah.

Populasi penelitian adalah semua peserta didik kelas V Sekolah Dasar Negeri 13 Ampenan. Sampel diambil menggunakan teknik random sampling. Sampel terdiri satu kelas kontrol dan satu kelas eksperimen. Untuk memperoleh data penelitian, digunakan instrument tes kemampuan berpikir kreatif berbentuk isian sebanyak 10 soal. Pengolahan data diawali dengan uji normalitas dan homogenitas, dan uji statistik anakova menggunakan SPSS for windows versi 20 untuk 
mengetahui pengaruh penerapan pendekatan saintifik menggunakan model pembelajaran discovery dan model pembelajaran kooperatif tipe
STAD terhadap kemampuan berpikir kreatif peserta didik SDN 13 Ampenan

Tabel. 1 Prosedur Pelaksanaan Eksperimen Pretes-PosttesNon Equivalen Control Group Design

Keterangan :

\begin{tabular}{lll}
\hline $\mathrm{T}_{1}$ & $\mathrm{E}_{1}$ & $\mathrm{~T}_{2}$ \\
$\mathrm{~T}_{3}$ & $\mathrm{C}_{1}$ & $\mathrm{~T}_{4}$ \\
$\mathrm{~T}_{5}$ & $\mathrm{E}_{2}$ & $\mathrm{~T}_{6}$ \\
$\mathrm{~T}_{7}$ & $\mathrm{C}_{2}$ & $\mathrm{~T}_{8}$ \\
\hline
\end{tabular}

$\mathrm{T}_{1,3,5,7}$ adalah nilai pretes; $\mathrm{T}_{2,4,6,8}$ adalah nilai posttes; $\mathrm{E}_{1}$ adalah Kemampuan tinggi dengan Model Pembelaran Discovery (MD); $\mathrm{E}_{2}$ adalah Kemampuan rendah dengan Model Pembelaran Discovery (MD); C1 adalah Kemampuan tinggi dengan Model Pembelajaran Kooperatif Tipe Student Team Achievement Divisions (MKSTAD); 2 adalah Kemampuan rendah dengan Model Pembelajaran Kooperatif Tipe Student Team Achievement Divisions (MKSTAD)

\section{HASIL DAN PEMBAHASAN}

Perolehan nilai rata-rata kemampuan berpikir kreatif peserta didik dengan kategori kemampuan tinggi dan rendah, tes awal dan tes akhir kelas eksprimen dan kelas kontrol dapat dilihat pada gambar 1 .

Hasil uji normalitas terhadap data pretest dan posttest hasil kemampuan berpikir kreatif peserta didik dapat ditampilkan pada tabel 2 berikut. Keputusan uji dapat dinyatakan normal jika memenuhi syarat $(\mathrm{Sig}>0,05)$ atau $\left(\mathrm{F}_{\text {hitung }}<\right.$ $\left.\mathrm{F}_{\text {tabel }}\right)$.
Hasil uji Homogenitas terhadap data pretest dan posttest hasil belajar IPA dan kemampuan berpikir kreatif dapat ditampilkan pada tabel 3 .

Uji hipotesis menggunakan analisis anakova dapat dilakukan karena telah memenuhi syarat, yaitu data berasal dari sumber yang homogen dan data terdistribusi secara normal. Hasil uji anakova dengan menggunakan SPSS versi 20 terlihat pada tabel 4.

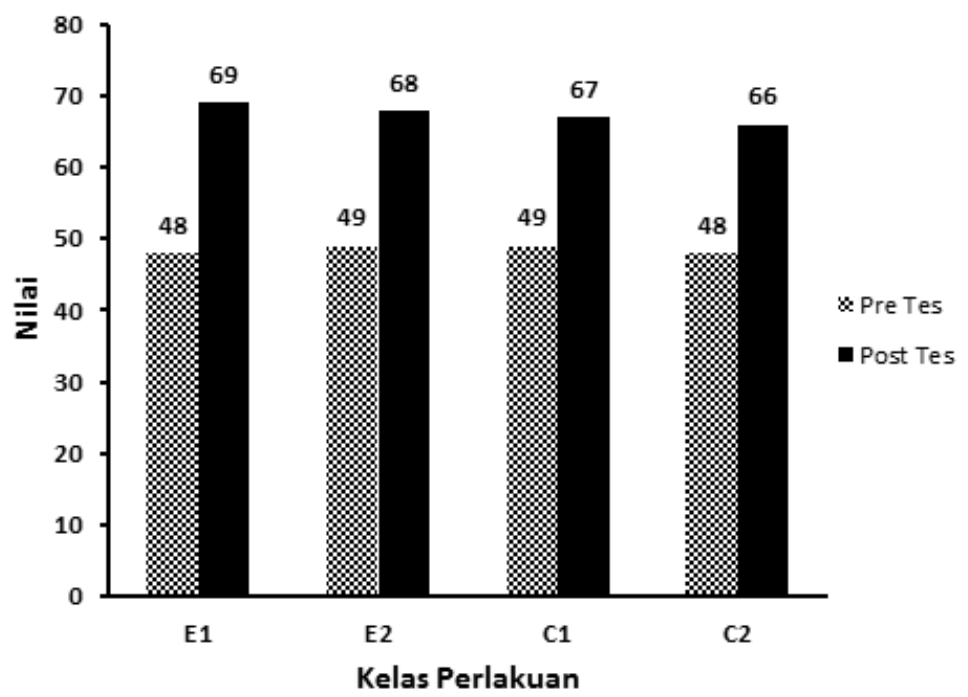

Gambar 1. Grafik Perbandingan Nilai Rata-rata Berpikir Kreatif Peserta didik Berdasarkan Kemampuan Tinggi dan Rendah

Tabel 2 Uji Normalitas Data

\begin{tabular}{lrrrrr}
\hline \multicolumn{1}{c}{ Sumber Data } & F hitung & df & Signifikan & F Tabel & Keputusan Uji \\
\hline Pretest Kemampuan Berpikir Kreatif & 5,80 & 11 & 0,88 & 19,67 & Terdistribusi Normal \\
Posttest Kemampuan Berpikir Kreatif & 8,05 & 10 & 0,62 & 18,30 & Terdistribusi Normal \\
\hline
\end{tabular}


Tabel 3 Uji Homogenitas Data

\begin{tabular}{llllllllll}
\hline \multirow{2}{*}{ Sumber Data } & \multicolumn{2}{c}{$\mathrm{N}$} & \multicolumn{2}{c}{$\mathrm{Df}=\mathrm{N}-1$} & \multicolumn{2}{c}{ Varian } & \multicolumn{2}{c}{$\mathrm{F}$} & Homogen: \\
\cline { 2 - 8 } & Eks. & Kon. & Eks. & Kon. & Eks. & Kon. & Hitung & Tabel & $\mathrm{F}_{\text {Hitung }}<\mathrm{F}_{\text {Tabel }}$ \\
\hline $\begin{array}{l}\text { Nilai Pretes } \\
\text { Kreatif }\end{array}$ & 35,00 & 35,00 & 34,00 & 34,00 & 123,14 & 91,78 & 1,34 & 1,77 & Homogen \\
\hline $\begin{array}{l}\text { Nilai Posttest } \\
\text { Kreatif }\end{array}$ & 35,00 & 35,00 & 34,00 & 34,00 & 117,26 & 76,53 & 1,53 & 1,77 & Homogen \\
\hline
\end{tabular}

Tabel 4. Hasil Uji Pengaruh Terhadap Kemampuan Berpikir Kreatif Peserta didik

\begin{tabular}{|c|c|c|c|c|c|c|}
\hline Sumber Data & $F_{\text {hitung }}$ & Sig. & Df & $\mathrm{F}_{\text {tabel }}$ & Keputusan & Kesimpulan \\
\hline $\begin{array}{l}\text { Posttest Berpikir Kreatif } \\
\text { Kelas Eksperimen }\end{array}$ & 1391,69 & 0,00 & $1: 35$ & 4,13 & Ha diterima & Ada pengaruh \\
\hline $\begin{array}{l}\text { Posttest Berpikir Kreatif } \\
\text { Kelas Kontrol }\end{array}$ & 2038,88 & 0,00 & $1: 35$ & 4,13 & Ha diterima & Ada pengaruh \\
\hline
\end{tabular}

Peningkatan kemampuan berpikir kreatif peserta didik dilakukan dengan melihat hasil tes yang diperoleh. Dari rata-rata hasil tes kemampuan berpikir kreatif peserta didik terdapat peningkatan nilai rata-rata peserta didik pada kelas eksperimen dan kelas kontrol. Rata-rata nilai pada kelas ekperimen kemampuan rendah meningkat dari 49 ke 68 , kelas eksperimen kemampuan tinggi meningkat dari 48 ke 69 dan rata-rata nilai pada kelas kontrol kemampuan rendah dari 48 ke 66 dan kelas kontrol kemampuan tinggi dari 49 ke 67.

Berdasarkan hasil penelitian diperoleh peningkatan kemampuan peserta didik yang menerapkan pendekatan saintifik menggunakan model pembelajaran discovery lebih tinggi dibandingkan dengan peserta didik yang menggunakan STAD. Pada proses pembelajaran peserta didik mencari sendiri permasalahan yang akan diselesaikan dan melakukan penelusuran dari berbagai sumber belajar, baik buku ajar, majalah, koran, maupun internet untuk mencari jawaban dari permasalahan yang akan mereka selesaikan. Proses belajar yang baru pertama mereka temui membuat pembelajaran lebih menarik, interaktif, efektif dan membuat peserta didik dapat menemukan konsep pelajaran yang akan disampaikan oleh guru. Ditunjukkan pada gambar 1dengan nilai rata-rata kelas ekperimen lebih tinggi dibandingkan dengan kelas kontrol.

Beberapa kelebihan model discovery dibandingkan dengan model kooperatif yaitu (1) Dalam penyampaian bahan, model pembelajaran discovery menggunakan kegiatan dan pengalamanpengalaman langsung dan kongkrit. Kegiatan dan pengalaman demikian lebih menarik perhatian peserta didik, dan memungkinkan pembentukan konsep-konsep abstrak yang mempunyai makna, (2) model pembelajaran discovery lebih realistis dan punya makna, sebab peserta didik bekerja langsung dengan contoh-contoh nyata. Peserta didik langsung mengaplikasikan kemampuannya, (3) model pembelajaran discovery merupakan suatu model belajar pemecahan masalah. Para peserta didik belajar langsung menerapkan prinsip-prinsip dan langkah-langkah pemecahan masalah, (4) transfer pengetahuan langsung dilakukan, sebab model pembelajaran discovery berisi sejumlah transfer, (5) model pembelajaran discovery banyak memberikan kesempatan pada peserta didik untuk lebih banyak terlibat dalam proses pembelajaran, kegiatan demikian akan banyak membangkitkan motivasi belajar, sebab proses pembelajaran akan disesuaikan dengan minat dan kebutuhan peserta didik [13].

Selanjutnya dilakukan pengujian untuk mengetahui pengaruh penerapan pendekatan saintifik menggunakan model pembelajaran discovery terhadap kemampuan berpikir kreatif. Hasil analisis terlihat pada tabel 4 bahwa pada posttest $\mathrm{F}_{\text {hitung }}=1391,698>\mathrm{F}_{\text {tabel }}=4,13$ maka $\mathrm{Ha}$ dinyatakan diterima dan tingkat kepercayaan $95 \%$ dapat dikatakan terdapat pengaruh penerapan pendekatan saintifik menggunakan model pembelajaran discovery terhadap kemampuan berpikir kreatif peserta didik.

Pengujian untuk mengetahui pengaruh penerapan pendekatan saintifik menggunakan model pembelajaran kooperatif tipe STAD terhadap kemampuan berpikir kreatif. Hasil analisis terlihat pada tabel 4 bahwa pada posttest $\mathrm{F}_{\text {hitung }}=2038,883 \mathrm{>}$ $\mathrm{F}_{\text {tabel }}=4,13$ maka Ha dinyatakan diterima dan tingkat kepercayaan $95 \%$ dapat dikatakan terdapat pengaruh penerapan pendekatan saintifik menggunakan model pembelajaran kooperatif tipe STAD terhadap kemampuan berpikir kreatif peserta didik.

Berpikir kreatif merupakan proses berpikir untuk mengembangkan atau menemukan ide atau 
hasil yang orisinil, estetis, konstruktif yang berhubungan dengan pandangan konsep dan menekankan pada aspek berpikir intuitif dan rasional [14]. Terlebih peserta didik akan dilatih untuk mampu berpikir memecahkan persoalan yang diberikan guru secara pribadi dan akan membantu peserta didik melatih proses berpikir secara mandiri dan kreatif. Karena berpikir kreatif merupakan keterampilan penting bagi setiap orang, tidak hanya pada saat belajar di sekolah, tapi juga ketika menghadapi dunia kerja [15].

Melatih kemampuan berpikir kreatif peserta didik dapat dilakukan dengan memberikan kebebasan peserta didik dalam menentukan topik/masalah yang akan dibahas terkait materi yang sedang dipelajari, mengajukan gagasan-gagasan dalam suasana yang saling menghargai sehingga mendorong peserta didik untuk berpikir divergen dan melakukan ekplorasi. Kemampuan berpikir kreatif menyebabkan hubungan sebab akibat, tergambar pada jawaban peserta didik yaitu: peserta didik dapat berpikir yang berlawanan tentang sesuatu hal, memikirkan penggunaan alternatif/cara melakukan sesuatu, membandingkan dua hal yang tidak berhubungan, menggunakan ciri-ciri acak suatu hal sebagai acuan dalam pemecahan masalah secara kreatif, memikirkan segala sesuatu disekitarnya dan merubah desainnya untuk membuatnya lebih sesuai.

Peningkatan kemampuan berpikir kreatif peserta didik dalam penelitian ini disebabkan penerapan model pembelajaran discovery yang merupakan perpaduan antara pendekatan saintifik dengan model pembelajaran discovery yang berpotensi mengembangkan kemampuan peserta didik. Menurut Rahmatina [9] peserta didik memiliki tingkat ingin tahu yang besar untuk menyelesaikan masalah, karena berpikir kreatif membuka banyak kemungkinan jawaban yang bisa mereka dapatkan dan menuntut untuk dapat memberikan bentuk atau cara baru dalam menyelesaikan masalah. Hal yang demikian merupakan suatu yang menantang dan menyenangkan bagi peserta didik untuk mencari tahu jawabannya.

\section{KESIMPULAN}

Berdasarkan hasil penelitian, dapat disimpulkan terdapat pengaruh pembelajaran dengan penerapan pendekatan saintifik menggunakan model pembelajaran discovery dan model pembelajaran koopratif tipe STAD terhadap kemampuan berpikir kreatif peserta didik dan pendekatan saintifik menggunakan model pembelajaran discovery lebih tinggi dibandingkan dengan peserta didik yang menggunakan model pembelajaran kooperatif tipe STAD.

\section{DAFTAR PUSTAKA}

[1] Ferdiansyah, F., Suherman, E., \& Yulianti, K. 2012. Penerapan Model Pembelajaran Osborn untuk Meningkatkan Kemampuan Berpikir Kreatif Matematis Siswa SMP.

[2] Aryani, M. F. 2014. Studi Kasus Penerapan Pendekatan Saintifik pada Guru-guru di SMA N 1 Bawang. Economic Education Analysis Journal. EEAJ 3 (3) (20014).

[3] Machin, A. 2014. Implementasi Pendekatan Saintifik, Penanaman Karakter dan Konservasi pda Pembelajaran Materi Pertumbuhan. JPII 3 (1)(2014) 28-35.

[4] Illahi, M. T. 2012. Pembelajaran Discovery Strategy dan Mental Vocatioanl Skill. Jogjakarta: Diva Press.

[5] Slavin, R. E. 2005. Cooperative Learning, Teori, Riset dan Praktik. Bandung: Nusa Media.

[6] Aryana, I. G. M. R., Al Idrus, A., \& Harjono, A. 2015. Pengaruh model pembelajaran kooperatif NHT dan STAD terhadap hasil belajar sikap siswa sma negeri 2 gerung. Jurnal pijar MIPA, 10(2).

[7] Yulianti, D. 2010. Penerapan pembelajaran kooperatif tipe stad untuk meningkatan aktivitas belajar dan hasil belajar ilmu kimia siswa SMAN 1 Natar Lampung Selatan. Jurnal pijar Mipa, 5(1).

[8] Afidah, I. N., Santosa, S., \& Indrowati, M. 2012. Pengaruh Penerapan Metode Socratic Circles Disertai Media Gambar Terhadap Kemampuan Berpikir Kreatif Siswa. Pendidikan Biologi, 4, 3, 1-15.

[9] Rahmatina, S., Sumarmo, U., \& Johar, R. 2014. Tingkat Berpikir Kreatif Siswa dalam Menyelesaikan Masalah Matematika Berdasarkan Gaya Kognitif Reflektif dan Impulsif. Jurnal Dikdakdik Matematika. 1, 1.

[10] Arnyana, I. B. P. 2007. Pengembangan Peta Pikiran untuk Peningkatan Kecakapan Berpikir Kreatif Siswa. Jurnal Pendidikan dan Pengajaran UNDIKSA, 3.

[11] Fauziah, Y. N. 2011. Analisis Kemampuan Guru dalam Mengambangkan Keterampilan Berpikir Kreatif Siswa Sekolah Dasar Kelas V pada Pembelajaran Ilmu Pengetahuan Alam. Edisi Khusus No. 2, Agustus 2011.

[12] Sugiono. 2012. Metode Penelitian Pendidikan Pendekatan Kuantitatif, Kualitatif dan R\&D. Bandung: Alfabeta. 
[13] Sukmadinata, N. S. 2005. Landasan Psikologi Proses Pendidikan. Bandung: PT Remaja Rosdakarya.

[14] Tristiantari, N. K. D., Marhaeni, A. A. I. N., Koyan, I. W. 2013. Pengaruh Implementasi Model Pembelajaran Kooperatif Tipe TPS terhadap Kemampuan Berbicara dan Keterampilan Berpikir Kreatif pada Siswa Klas
V SD Negeri Gugus III Kecematan Seririt. EJournal Jurusan Pendidikan Dasar. 3. .

[15] Fardah, D. K. 2012. Analisis Proses dan Kemampuan Kreatif Siswa dalam Matematika Melalui Tugas Open-Ended. Jurnal Kreano, ISSN : 2086-2334. Jurusan Matematika FMIPA UNNES, 3, 2. 